\title{
The Politics of Security and Secularism in Turkey: From the Early Republican Era to EU Accession Negotiations*
}

\author{
Pinar Bilgin
}

\section{Introduction}

Policy discourse and academic accounts alike are characterized by a sharp divide concerning the nexus between security and secularism ${ }^{1}$ in Turkey. On the one hand are those who consider the 'state establishment's ${ }^{2}$ interpretation and practices of secularism as unduly restricting the rights and freedoms of 'the pious' (Muslims and non-Muslims). On the other hand are those who consider any kind of challenge to the status quo regarding this matter as a threat to 'national security.' Historically, both perspectives have had their supporters inside and outside Turkey. A coalition of international actors has, for long, been supportive of the state establishment's practices ${ }^{3}$ as the best form of defense against the threat of the rise of irtica (reactionarism). More recently, a growing number of actors including the European Union (EU), ${ }^{4}$ the United States State Department, ${ }^{5}$ and Pope Benedict XVI (Weigel 2006) have been critical of the very same interpretation and practices due to the adverse consequences they have had for the freedom of religion in Turkey. What has drawn the two positions further apart is the emergence of the AKP movement ${ }^{6}$ (Adalet ve Kalkınma Partisi, Justice and Development Party) 
in the late 1990s and its break with the National Outlook tradition (Milli Görüs Hareketi) to adopt a more positive stance toward secularism and seek Turkey's accession to European integration. Particularly critical has been the AKP's attitude toward secularism, which took the form of reaffirming its commitment to the separation of religion and state although underplaying the need for creating the norms and mechanisms that would regulate the behavior of individuals who approach their private lives as well as official duties through the prism of religious interpretations.

This chapter seeks to move beyond prevalent portrayals of the nexus between security and secularism in Turkey as a clash between the EU-oriented AKP movement who seeks freedom of religion, and the state establishment that targets irtica as a threat to Turkey's security. In what follows, I present a 'security reading' of two slices of Turkey's history: the early Republican leaders' turn to secularism during the 1920s, and the AKP movement's post-1997 embrace of secularism and 'EU-ism' (abcilik, a shorthand used to refer to those who favor Turkey's accession to European integration). The aim here is to offer fresh insight into the nexus between security and secularism in present-day Turkey by historicizing the differences between the security concerns of the state establishment on the one hand and the AKP movement on the other. It is argued that although the former has viewed secularism as a part of the overall strategy of securing Turkey as a unitary and democratic state (through pushing religiously justified arguments and identity claims outside the realm of politics), the latter has come to consider Turkey's accession to European integration as the only viable strategy for securing a life-space for 'pious' Muslims in post-9/11 world politics. ${ }^{7}$ Accordingly, the chapter offers a reading of Turkey's politics that allows understanding the dynamics of the relationship between the state establishment and the AKP movement within the framework of 'security versus security' — and not 'security versus (freedom of) religion.'

There are numerous benefits to be accrued from reframing the terms in which contemporary dynamics are understood. First, focusing on the politics of security and secularism in early Republican era would allow greater insight into the processes through which secularism has come to be considered as a security referent (i.e., who/what needs to be secured) in the Republic of Turkey. Second, it would allow understanding the AKP movement's post-1997 stance toward secularism and its embrace of EU-ism as a solution to the perceived insecurities of the self-constituted community of 'pious' Muslims in Turkey. Presenting a security reading as such could potentially help jump-start a dialogue on the insecurities of both sides and possible ways of addressing those insecurities. Last, but not the least, the particular way of understanding the nexus between security and secularism 
offered in this chapter allows fresh insight into the dynamics of Turkey's accession to European integration, in particular the processes through which the AKP movement has distanced itself from the anti-EU stance of the National Outlook tradition, while the state establishment has come to express doubts about the implications of EU membership for Turkey's security.

The argument proceeds in two steps. The first part shows that in early Republican leaders' approach, secularism emerged as a security referent not only because it was 'a way of life' but also because secularism, at the time, contributed to the efforts designed to defend the sovereign Republic against internal and external threats (including reactionarism and sectarianism 'inside' and great power interventionism 'outside'). Viewed as such, secularism was something that deserved to be protected not only on its own merits, but also because it helped to protect many other achievements of Republican transformation (including women's emancipation). The second part shows that the AKP movement's attitude toward secularism and the EU could be read as steps taken toward locating Turkey firmly within the pluralistic realm of 'Europe' toward creating room for 'the pious' to lead their lives free from state interference. ${ }^{8}$ What distinguishes the two is what they seek to secure: the state, the regime, and the achievements of Republican transformation are the security referents for the state establishment whereas the AKP movement focuses on the well-being of the self-constituted community of 'pious' Muslims-an aspect but clearly not the whole of Turkey's society.

\section{The Early Republican Era and Turkey's Turn to Secularism}

During his tenure as president of the Republic (2000-2007), Ahmet Necdet Sezer delivered numerous speeches that touched upon the problem of irtica and the kind of threat it poses to secularism in Turkey. "During the past twenty years, irtica has grown to be a bigger threat," the president warned at the 2006 opening ceremony of the Grand National Assembly. After briefly describing the various forms irtica assumed and the kind of threat it posed to secularism, President Sezer reminded his audience "[S]ecularism is the cornerstone of the [Turkish] revolution. The principle of secularism is the cornerstone of all values that constitute the Republic of Turkey."

President Sezer's way of framing irtica, which finds its echo in the discourses of the military (Büyükanıt 2006) and aspects of the academia (Kili 2003), portrays it as a threat to secularism, which, as a result, is viewed as the referent object of security. It is implied that the ultimate 
referent object is the Republic of Turkey, and that secularism is important because it is a constitutive principle of the Republic. Yet, more often than not this last part of the argument gets dropped out of political discourse; in its stead, the public is presented with the "secularism as a way of life"10 argument. Clearly, the centrality of secularism to Turkey's politics needs to be argued in a more compelling manner with a view to clarifying the nature of its securityness. In what follows, I offer such an argument and show that understanding the enduring centrality of secularism demands a fresh reading of the early Republican period.

Some scholars have sought to explain the early Republican turn to secularism as a function of Mustafa Kemal Atatürk's disposition to Islam. Atatürk's speeches, however, reveal seemingly conflicting positions on Islam. ${ }^{11}$ Whereas in some speeches he refers to Islam as the most "rational and natural of all religions," in others he comes across as disapproving, especially in terms of its effects on the society: "[T]he Republic of Turkey cannot be the country of sheiks, dervishes, disciples and members of sects. The most correct-the most genuine-sect is that of civilization" (cited in 75 Yılda Düşünceler Tartışmalar 1998: 241, 247).

Scholars who have sought to understand Atatürk's position on Islam by historicizing and contextualizing these remarks within the timeline of Republican transformation have not provided more insight. Whereas some argue that Atatürk sought to adopt a 'radical' approach toward Islam from the beginning and that his 'mild' commentary from the early years should be considered as a sign of his pragmatism (as with the call for jihad in the early years of the National Struggle, see, for example, Tanör 1955: 66, Kili 2003), ${ }^{12}$ others view the gradual hardening of his position not as a consequence of a grand design but of circumstances (Davison 1998).

Those scholarly explanations that focus directly on Atatürk's rationale in turning to secularism are no less entangled. For some, secularism was adopted because the Ottoman experience had proven the futility of attempts to modernize the state and the society without removing Islam as the prevailing set of ideas. ${ }^{13}$ For others, secularism has served as a "governance technique" in Foucauldian terms, helping to keep the 'periphery' at bay (Mardin 1977). Notwithstanding their differences, the two sets of accounts converge on reading the dynamics of the 1920s through the lenses of the contemporary era and end up overemphasizing the internal dynamics to the neglect of the international. Where the two accounts differ is that while the former considers Islamist activism as a perennial threat to secularism, the latter thinks of it almost as an emancipatory movement organized to resist the secularizing reforms of the Republican leadership. 
The scholarly literature's neglect of the 'international' is somewhat surprising, because Atatürk was the leader of an antiimperialist independence movement before he became a state-builder. During the National Struggle (1919-1922), Atatürk fought against not only the Sultan, but also imperialism-its forces as well as ideology. The 'international' dimension of Atatürk's (and other early Republican leaders') thinking is far too significant to be left out of scholarly analyses. I will make three points. First, there is an international dimension to the abolishment of the caliphate; it had to be abolished partly because it was complicating relations with the great powers. In Halide Edip Adıvar's words, "[t]hey either suspected Turkey constantly of scheming against their sovereignty, or else they themselves were involved in intrigue in Turkey in order to get control of the Caliphate and use it on behalf of their own ambitions" (cited in Kili 2003: 356). Such concerns were not unjustified. Beginning with Sultan Abdülhamid, the Ottoman Empire had sought to make active use of the caliphate in the attempt to substantiate its status as a "great power" vis-à-vis the European great powers. Its efforts had paid off to an extent; Muslims worldwide responded to Ottoman maneuverings in a way that made the colonial powers uncomfortable (Deringil 2007). Abolishing the caliphate in 1924 removed a cloud of suspicion regarding the international political ambitions of the Republican leadership. As a result, it removed the grounds for future intervention into Turkey's affairs.

The second and related point is about the justifications the great powers of Europe had used to interfere on behalf of non-Muslim subjects of the empire. During the Lausanne Treaty negotiations, members of the delegations of European powers had challenged Turkey's jurisdiction over non-Muslim citizens and wanted to maintain the right to intervene on their behalf. The principle of secularism was adopted partly to prevent such interference and sustain Turkey's sovereign existence. The Minister of Justice Mahmut East Bozkurt provided the following rationale when presenting the draft bill of the Turkish civil code to the Grand National Assembly in 1926. It is worth quoting him at length:

Especially in states that contain subjects belonging to various religions, in order to acquire the ability of carrying out a single law in all of the community, this severing of relations with religion is a requisite for the sovereignty of the nation. This is because if the laws will be based on religion it becomes necessary for the state that is faced with the necessity of accepting freedom of conscience to make separate laws for its subjects belonging to several religions. This situation is totally opposed to the political, social, economic, and national unity that is a fundamental condition in states of the present century. It is necessary to remember that the state is not only in contact with its subjects, but also with foreigners. In this 
case it becomes necessary to accept special stipulations for them under the name of capitulations. This point has been the most important aspect of the rationale used by foreigners for the preservation of our country of the capitulations that are abolished in the Lausanne Treaty. (full text available in Davison 1998: 197-203)

Bozkurt's words underscore yet another 'international' dimension of the Republican leaders' turn to secularism: to prevent interference into the affairs of the state on behalf of non-Muslim citizens.

There is a third 'international' dimension to early Republican policy making: the project of modernization and 'gaining respect in the eyes of the civilized world' as a solution to a security problem. As with Ottoman modernization, Turkey's modernization is usually explained with reference to the attempt to 'reach the level of contemporary civilization'. In such explanations, the 'international' dimension is acknowledged, but modernization is represented either as a 'lifestyle choice' or as a pure instrumental move to prevent military decline. Yet, both Ottoman and Turkey's modernizations were more than that. They were designed to become a member of the 'contemporary civilization' to not only give an end to battlefield losses but also to remove the ground for European interventions and the claims to the right to "better" rule non-European people. One of Atatürk's closest friends, Falih Rifkı Atay, put the choices facing Ottoman statesmen at the time in dramatic terms when he wrote: "We were either going to become European or ... the seven-fanged imperialist beast called Düveli Muazzama [great powers] was going to break us up and turn into Asian hordes" (Atay 1961: 447).

The Ottoman Empire had a firsthand experience of European claims to the right to 'better' rule when the British took over Cyprus and sought to legitimize their continued occupation of the island through invoking the superiority of enlightenment and post-enlightenment ideas that they introduced to replace what they portrayed as the 'useless' and 'impractical' education systems of the Greeks and Ottoman Turks (Bryant 2001). Postcolonial movements around the world have had to fight not only the forces but also the culture of imperialism. For, the latter allowed the former to occur (see Said 1993).

In other parts of the world, reactions to such claims to better rule had taken the form of seeking to remove the grounds for the claim to such superiority. Homi Bhabha terms the strategy adopted by the colonized as "mimicry" - an attempt made by the "weak" to resist the "strong" by becoming similar. The colonized feigned similarity, because it was based on a hierarchical classification of nations ("civilized" versus the "rest") that colonialism had been justified for years. Perhaps because the 
Ottoman Empire was never colonized, insights gleaned from postcolonial studies are rarely applied to the study of Turkey. ${ }^{14}$ Yet they prove useful in understanding the trials and travails of modernization in late Ottoman and early Republican periods. Although the Ottoman Empire was never colonized, the threat of colonization remained immanent (in Turkey's leaders' minds if not in 'reality') well until the consolidation of the Republic. ${ }^{15}$ Following the insights of postcolonial International Relations, Early Republican transformation, as with other modernization projects in some other parts of the developing world, could be understood as mimicry. Since the colonizer's claim to rule rested on being modern as opposed to the traditional ways of the colonized, merely fighting the colonizer on the battlefield was not enough. It was also necessary to remove the ground for his claim to "better" rule. Viewed as such, the project of modernization in early Republican Turkey could be read as part of the attempt to become similar (i.e., modern, a member of the "contemporary civilization") so as to minimize external interference and to make room for sovereign development.

The justifications provided for the adoption of the hat as the headgear in 1925 serve to illustrate this point. At the time, early Republican leaders portrayed the $f e z$ as a symbol that marked the Turks' difference from the 'contemporary civilization'. They maintained that the adoption of the hat as headgear would help the world know that the Turk was no longer different but similar to them: that the Turk also "has the right to live and be happy"; that the Turk is "a whole new world, with no difference from yours ... The Turk is a person like you, wishing to make use of the fruits of the civilization." Adopting the hat as the headgear was expected to help in getting this message across because "it was easier to show what was outside one's head compared to what was inside" (cited in 75 Yilda Düşünceler Tartışmalar: 211, see also Berkes 1963: 473-474). What is interesting for the purposes of the argument here is that the hat was framed by early Republican leaders in terms of the survival of a people and a transformative movement, and not as a mere lifestyle choice.

To recapitulate, secularism, as the centerpiece of the project of modernization in Republican Turkey emerged to be a referent of security not only because it was a choice of lifestyle or only due to its emancipatory gains (that were many), but also because it helped to secure the Republic against threats emanating from both 'inside' and 'outside' the country. Together with the previous two, these three 'international' dimensions to the adoption of secularism have so far been neglected by existing accounts. Capturing the international dimension of early Republican leaders' turn to secularism as such is crucial in so far as it allows a fresh reading of the politics of security and secularism in the Republic of Turkey. Contra 
prevalent (and rather one-dimensional) accounts that superimpose contemporary era portrayal of irtica as a security threat on to the 1920s' dynamics, the account offered here clarifies the central concerns of early Republican leadership. It is argued that secularism has become the referent object of security not only due to its emancipatory gains, but also by virtue of its contributions to the efforts to secure Turkey against internal and external threats. Outside, it helped to maintain state security against interference by the great powers. Inside, it helped to provide regime security against a variety of domestic rivals and challenges while bolstering the Republican transformation project by bridging across sectarian divides. Capturing this status of secularism as an aspect of Republican security strategy allows understanding the securityness of secularism in present day Turkey in a way that the alternative accounts do not. To reiterate, this is not to underestimate the significance of the emancipatory gains of secularism for the Republican transformation or its approval as a lifestyle choice by large segments of the population, but to underscore the concerns of the state establishment (and those who took to the streets in the spring of 2007). Recovering this international dimension through a security reading is important to understand early Republican leaders' turn to secularism; for it is based on particular representations of early Republican policy making that present-day debates regarding Turkey's accession to European integration are shaped. ${ }^{16}$

\section{The AKP Movement's Stance toward Secularism and Embrace of "EU-ism"}

On November 3, 2002, for the first time in Turkey's Republican history, a political party that defines itself by its founders' 'conservative democrat' credentials got 34.28 percent of the overall vote (that translated to 363 out of 550 members of the Grand National Assembly) ${ }^{17}$ and subsequently formed the government. Less than five years later, in an early election that took place on July 22, 2007, the percentage of its votes increased to 46.7. Adalet ve Kalkinma Partisi was initially considered as yet another political party in the mould of the National Outlook tradition, which was defined by its project of "capturing the state and using it to bring about changes in society by adopting the centralism of the Republic" (Mardin 2005: 160). They were different, AKP leaders promised, in that they no longer sought to change Turkey in their own image. They wanted to make the "system work justly for all its constituents rather than overthrowing it" (White 2002: 139). The AKP leadership marked their new stance with an EU-oriented election manifesto. ${ }^{18}$ 
Those few scholarly studies on the rise of the AKP concur on the issue of what distinguishes it from previous parties of the National Outlook mould: its relationship to the newly transformed Islamist activism in Turkey. ${ }^{19}$ In the period following the so-called postmodern coup of February 28 1997, aspects of Islamist activism in Turkey went through a process of transformation whereby their "anti-European" stance was dropped in favor of seeking Turkey's accession to European integration. Prevalent understandings of the AKP movement portray its turn to secularism and EU-ism as an effect of the 1997 coup, which is considered to have driven the lesson home that given the nature of the consensus over secularism within Turkey's state establishment, redesigning the system was not a possibility. In the eyes of the group who broke away from the National Outlook tradition, Turkey's accession to European integration promised protection of 'religious freedoms' in a way Turkey's current interpretation and practices of secularism could not. Viewed as such, the AKP leadership could be considered as seeking to emulate the EU practice of creating a more pluralistic society, which, they expect, would allow some to lead a self-styled Islamic way of life free from state interference while others lived by their own values.

Although the impact of the international context barely gets a mention in accounts on the AKP's transformation, it is difficult to imagine the founders of the AKP not being influenced by the not-so-bright prospects of carrying an "Islamist" agenda in the seemingly "Islamophobic" world politics of the post-9/11 era. Taken together, the internal and external aspects of insecurity facing Islamist activism in Turkey renders the AKP movement's embrace of secularism and EU-ism a solution to a complex problem of the insecurities experienced by "the pious." Contra those readings of the transformation of the AKP movement as an "experiment with pluralism" (Prodromou 2005: 16) or "a different form of secularism" (Hurd 2006: 415), I argue that it is better understood as part of an attempt to address the societal insecurities of pious Muslims in Turkey in the face of the hardships they faced at home and abroad. The society of 'pious' Muslims is the referent object of this security strategy. As shown, the AKP leadership's record so far does not amount to transforming Turkey toward embracing greater pluralism and freedom for all. Not just yet. My intention here is not to underplay the importance of the AKP movement's difference from the National Outlook tradition or to revamp the secret agenda accounts of the AKP movement. ${ }^{20}$ Rather, by presenting a security reading, I seek to point to the limits of the changes made thus far, and open up room for dialogue within a 'security versus security' framework.

To do this, I draw upon the concept of societal security (see Waever, Buzan, Kelstrup, and Lemaître 1993, Buzan, Waever, and de Wilde, 1998). 
Different from national security, which prioritizes the concerns of states on behalf of their citizens, societal security refers to the concerns of groups of individuals who constitute themselves as a community via their shared insecurities and interests (see McSweeney 1999). It is often the case that societal security concerns are identified in contradistinction to state practices that may allow unchecked migration, or threaten the identity and interests of a group of people through integration projects and/or allowing one group to culturally or linguistically assimilate the other (Buzan, Waever, and de Wilde 1998: 119-121). The Republican transformation could be considered to have given rise to similar concerns in Turkey by way of causing a sense of powerlessness and defeat on the part of those whose identities and interests were tied up with more conservative interpretations of Islam and its role in the shaping of society and politics. In turn, the AKP movement could be viewed as the latest reincarnation of the struggle to resist the secularizing forces of the Republican transformation in the attempt to address the insecurities of the pious who felt marginalized in the political if not societal realm.

The centrality of societal insecurities to the AKP movement's embrace of EU-ism crystallizes in the below-quoted testimony of Bülent Arınç, founding member of the AKP and speaker of the Grand National Assembly during 2002-2007. Pointing to 1997 as a critical turning point in his political career, Arınç said, "February 28 turned me into an EU-ist" "'Beni 28 Şubat abci yaptı"). It is worth quoting him at length:

We used to have a different understanding of the state; the leviathan, with a scowl, that reminded one of the gendarmerie and the police ... [After February 28] we came to see the need for an understanding that rejects treating the state as sacred, that better protects the individual, delivers services to him/her. What is important is the individual; his/her welfare, peace of mind ... This is how we came to believe in the EU goal. Locating oneself in the free world ... (Yetkin 2005)

In Arınç's words one can find evidence for two different readings of the AKP movement. His words could be taken to suggest that the AKP movement is an attempt to escape the state establishment's interpretation and practices of secularism through making it possible for a more pluralist outlook to prevail in Turkey. Arınç's words could also be read as an attempt to circumvent a state- and regime-focused understanding of security (note his emphasis on decentering the state) and replace it with a societal-focused understanding that prioritizes the concerns of the community of the pious. ${ }^{21}$ Without wanting to underestimate the significance of the reform packages passed during the early years of the AKP 
government, which support the first reading, I nevertheless weigh in on the side of the second.

Let me clarify. Creating a pluralist environment for those that uphold different interpretations and practices of various religions to coexist would have required the adoption of what Nilüfer Göle has referred to as "consensual secularism," understood as "giving up the absolutism of the religious truth-regime" (Göle 2006: 257). The AKP leadership's approach to intra-Islamic issues suggests that they are prone to closing off debates on issues that they hold to be sacred as opposed to recognizing a plurality of perspectives. The AKP movement has so far repeated their stance that practices of secularism should be limited to the 'separation of religion and state' ${ }^{22}$ and need not involve the 'secularization of consciousness'. Yet, consensual secularism would require the creation of norms and institutions that would regulate the behavior of individuals who approach their lives and their official duties through religious interpretations. The absence of such norms and institutions has so far disallowed discussions on the multiple interpretations of the sacred and their implications for politics.

Let me illustrate this point with reference to women's security. There is a politics to the interpretation of religious texts, as evidenced in the many writings of Fatima Mernissi (1991) and Amina Wadud (2006) on women's rights in Islam. The AKP movement, while calling for religious freedom and pluralism, does not recognize plurality of interpretations within Islam vis-à-vis women's rights. The gruesome end of Muslim feminist Konca Kuriş $^{23}$ is an example of the limits of tolerance among Turkey's 'pious' on this very issue. Consider, also, Prime Minister Erdoğan's reaction to the European Court on Human Rights (ECHR) ruling on women students' wearing of headscarf in universities. When the court ruled that the ban did not constitute a human rights violation, Prime Minister Erdoğan said the following:

The court has no right to speak on this issue. That right belongs to the ulema [religious experts]. You should be asking someone who belongs to that religion, be it Jewish or Christian whether this is a strict religious duty for them. If it is, you have to respect that. Otherwise, it becomes something else, political, ideological. That is something else. If this has a place in religion, you have to respect that ... I say there is a place for this [headscarf as a religious duty] in religion. I have read the scholarly writings on this subject ... It is wrong that those who have no connection to this field make such a decision without consulting the ulema. (cited from Başbakanımız mürekkep yalamış, Radikal, November 11, 2005)

It is beyond the purposes of this chapter to discuss the ruling of the ECHR and the prime minister's criticism that this goes against the freedom 
of religion (see Hurd 2006, especially pp. 413-414 for a discussion). What is significant for my purposes here is that, Prime Minister Erdoğan, in clear defiance of power/knowledge relationships within Islam, overlooked multiple interpretations on this issue in Turkey and elsewhere. ${ }^{24}$ Significant implications flow from a prime minister's representation of one interpretation as the religious 'truth' while denying the existence of alternatives. Such attempts to discipline those who belong to Islam via invoking the absolute of religious truth would sit uneasily with the principle of religious freedom that the AKP leadership has asked to be more vigorously applied in Turkey. Hence, my point that the AKP movement's current stance on the issue of religious freedom falls short of a reinterpretation of secularism (along the European Union or US model) but an attempt to 'control' ${ }^{25}$ religion in its own way-as opposed to the state establishment's ways.

\section{Conclusion}

This chapter sought to present fresh insight into the nexus between security and secularism in Turkey by historicizing the differences between the state establishment and the AKP movement through a security reading. The analysis first clarified the centrality of secularism in Turkey's politics. The degree of such centrality cannot be underestimated. Secularism has served to secure the state and the regime as well as helping to emancipate women. Viewed as such, any challenge to the prevailing understanding and practices of secularism would have to reconcile multiple insecurities of the aforementioned referents together with other potential (or actual) referents. It then, second, reframed the terms within which Turkey's current dynamics are understood by presenting a reading of the AKP movement as motivated by concerns about securing a life-space in post9/11 world politics for the self-constituted community of the pious. The steps the AKP movement has taken to address such insecurities, as with the turn to secularism and embrace of EU-ism, seem to have taken Islamist activism in Turkey to a different future. That said, the AKP movement, by virtue of privileging the security concerns of a fraction of the populace, has so far fallen short of the European ideal that it professedly aspires to import to Turkey.

Presenting a security reading as such crystallized the differences between the state establishment and the AKP movement regarding whose security they prioritize. It also identified the blind spots of both regarding women's security. To start with the AKP movement; the only aspect of women's insecurity it problematizes is the state establishment's refusal to let women to wear a headscarf in public spaces. ${ }^{26}$ Otherwise, the AKP movement is 
concerned with the insecurities of referents other than women. What the AKP leadership emphasizes is the need to marginalize state- and regimefocused security concerns and adopt an understanding of secularism "crowned with democracy in order for fundamental rights and freedoms to be accorded constitutional guarantees" (Erdoğan 2004). Here emerges one of the limitations of the AKP movement's definition of 'fundamental rights and freedoms'-its failure to incorporate women's rights into 'human rights.' Discussing whether women's right to wear a headscarf constitutes an integral aspect of human rights is beyond the confines of this chapter. What is significant for my purpose here is that the AKP movement (as evidenced in the words of Prime Minister Erdoğan quoted earlier) does not recognize Muslim women's right to believe that wearing a headscarf is not a religious duty. What the AKP movement is currently asking for is the right for the self-constituted community of the pious to lead an Islamic way of life in Turkey. What the AKP leadership has not been willing to tolerate is the right of Muslims other than the self-constituted community of the pious to question what is Islamic and what is not. By way of defining the wearing of headscarf by women as a religious duty sanctioned by the ulema, the AKP movement has disallowed the questioning of power/ knowledge relationships within Islam, while allowing another insecurity to continue-women's insecurity that could be traced back to earlier periods in Islamic and Ottoman history. ${ }^{27}$

Interestingly, institutions of the state establishment do not always disagree with the AKP on this matter. The Presidency of Religious Affairs, the Diyanet İşleri Başkanlı̆̆l, has time and again opined (to the neglect of multiple interpretations that it fails to acknowledge) that wearing a headscarf is a religious duty. ${ }^{28}$ Accordingly, the state establishment, while emphasizing the significance of secularism for women's insecurities, has nevertheless allowed some of them (but clearly not all) to continue by failing to inquire into power/knowledge relationships within Islam. It is impossible to know what would have transpired if conditions allowed the implementation of the recommendations of committee on reform in worship, which was set up by Atatürk in 1928. Since they could not be implemented, some (but clearly not all) of women's insecurities remained. Throughout Republican history, while one institution of the state has warranted the wearing of headscarf as a religious duty, others have discouraged its use. Clearly, the 1920s solution, namely "making it disadvantageous for any but the old [to wear a headscarf]" (Berkes 1963: 474) is no longer sufficient. What is needed is new thinking on the nexus between security and secularism with a view to the insecurities of multiple referents, including the state, regime, the self-constituted community of 'the pious' (Muslims and non-Muslims), and individuals qua individuals (men and women). 


\section{Notes}

* An early version of this chapter was presented at the University of CopenhagenDanish Institute of International Studies co-organised conference in January 2007. Later versions were presented to the European Studies Research Group of the Department of International Politics, University of Wales, Aberystwyth, in February 2007, and at the ECPR Standing Group on International Relations (SGIR) Conference in Turin, Italy, 12-15 September 2007. I would like to thank my co-panelist Ole Wæver and other participants for their comments and criticisms. Most of the research for this chapter was conducted during my residency as a fellow (2006-07) at the Woodrow Wilson International Center for Scholars, Washington, DC, while working on a broader project on security culture in Turkey.

1. Andrew Davison (1998) distinguishes between laicism and secularism in Turkey's context and favours the former as the more accurate description of the intentions as well as consequences of the Republican project. I will nevertheless use the term 'secularism' to refer to Turkey's laiklik principle and the policies that flow from it.

2. Here, 'state establishment' refers to the bearers of the prevailing ideology of the state, a.k.a. Kemalism.

3. Such practices have included the ban on the use of headscarf by female students and public employees, the closing down of political parties suspected of harbouring a reactionary agenda, and the 1997 coup, which resulted in the fall of the coalition government led by a party (RP, Welfare Party) of the 'National Outlook' tradition.

4. The European Union's 2006 Progress Report on Turkey is available at http:// ec.europa.eu/enlargement/pdf/key_documents/2006/Nov/tr_sec_1390_ en.pdf. (accessed 8 January 2007).

5. The US State Department's 2006 International Religious Freedom Report on Turkey is available at http://www.state.gov/g/drl/rls/irf/2006/71413.htm. (accessed 8 January 2007).

6. 'AKP movement' refers to new thinking and activism that has allowed for and evolved together with the emergence of a new group within the National Outlook movement of Necmettin Erbakan. For an anthropological account of the characteristics and emergence of the AKP movement, see White (2002).

7. Needless to say, there is no single interpretation or practice of secularism within the European Union. What is more, the leaders of the AKP movement have expressed interest in reinterpreting secularism along the Anglo-Saxon model, which is closer to United States than European practice (see, for example, "Yine yeniden türban," Radikal, February 7 , 2005, Babahan 2005).

8. The troubles the project of multiculturalism has faced in the European Union in recent years suggest that Europe is far from constituting the pluralist safe-haven as portrayed by the AKP movement. Nevertheless, such portrayal has allowed the members of this movement to embrace EU-ism. 
9. “AKP'ye bir 'irtica' uyarısı da Sezer'den” Radikal, October 2, 2006.

10. “Sezer Din Şurasında Cemaat Uyarısı Yaptı,” Sabah, September 21, 2004.

11. As on some other issues. Some explain this with reference to his pragmatism and genius as a politician (see Koçak 2006).

12. Islamist readings converge with that of Kemalists on what I call the 'grand design' explanation-that Atatürk had set out to apply this radical agenda from the very beginning.

13. See, for example, Ozankaya (1981), Yavuz (1990), Kili (2003). Some also call attention to secularism as the culmination of two centuries of Ottoman attempts at modernization thereby writing secularism back into history (see Berkes 1963). There is also another set of contributions that write secularism into the history of even earlier periods such as Hazar Turks of the seventh century and the Seljuk Empire (see Kafesoğlu and Saray 1983). Having said that, there is a limit to how much parallel could be drawn with the Ottoman experience. Although the Empire was 'secular' in some ways (as with the isolation of 'Islamic law' to private affairs and the room granted to different faith communities [millet] to practice their own law) it still derived its legitimacy from a mix of pre-Islamic (Hassan 2001) and Islamic codes of meaning and behavior.

14. Deringil (2007) is a noteworthy exception to this generalization. It is significant to note here that the Ottoman Empire justified its imperial practices through invoking a different system of meaning than Orientalism. Still, as Deringil points to, during the latter years of the empire, it also followed the example of the Orientalist tradition in orientalizing its own 'east'-as with the lands in Africa.

15. Hence the resilience of the Sèvres syndrome in Turkish security discourse (Bilgin 2005, 2007)

16. See Bilgin (unpublished) for further discussion.

17. Election results are available at http://www.belgenet.com $/$ secim $/ 3 \mathrm{kasim} . \mathrm{html}$ (accessed January 14, 2007).

18. Although the AKP movement has adopted a position in tune with the demands of the globalizing world economy, its stance on family and women's issues seems to have deviated little from that of the National Outlook tradition. See below.

19. See White (2002) for an anthropological account of the transformation that resulted in the foundation of AKP. Yavuz brings together sympathetic accounts of this transformation from a variety of scholarly and nonscholarly perspectives (Yavuz 2006).

20. The AKP is suspected of planning to alter delicate balances in Turkey under the guise of meeting EU conditionality. See an interview with Mustafa F. Ağaoğlu, former chief advisor to the National Security Council: " 28 Şubat ders oldu, Ak Parti kurbağayı soğuk suya koyup altını öyle yaktı," Referans, December 6, 2006.

21. Again, the aim here is not to regurgitate the "secret agenda" or takiyye arguments, but to point to the limits of the AKP's break with the National Outlook tradition. 
22. For Prime Minister Erdoğan's definition of secularism, see, "Yine Yeniden Türban," Radikal, February 7, 2005. For the then speaker of the parliament, Bülent Arınç's definition, see his address to the Grand National Assembly on the occasion of April 23, available at www.yenisafak.com.tr/dosya/arinc_ tbmm_23042006.html (accessed October 19, 2007). Also see President Gül's definition, which is different in terms of his emphasis on aspects of secularism other than the institutional separation of religion and state. See 'Gül'ün laiklik tanımı tartışılıyor,' NTV, August 31, 2007 (available at www. ntvmsnbc.com (accessed October 15, 2007).

23. She was captured and tortured to death by the Hizbullah in Turkey. Ironically, neither the fundamentalist cadres nor Turkey's feminists took up her case as one of their own.

24. Whereas some consider it a religious duty, others read it as a product of a particular time and place (see Mernissi 1991, Wadud 2006).

25. See Davison (1998) for a discussion on the "control" account in Turkey Studies.

26. The definition of "public space" is contested.

27. Consider the position of the last Şeyh-ül İslam of the Ottoman Empire, Mustafa Sabri Efendi on this issue (also see Mernissi 1991).

28. See an interview with the president of religious affairs, Ali Bardakoğlu, CNNTürk, available at http://www.diyanet.gov.tr/turkish/default.asp\# (accessed October 19, 2007).

\section{References}

75 Yılda Düşünceler Tartışmalar (1998), İstanbul: İş Bankası Yayınları.

Atay, Falih Rıfkı (1961): Çankaya, Ankara: Bateş.

Babahan, Ergun (2005): Laisite ve Sekülarizm, Sabah, May 30.

Başbakanımız mürekkep yalamış (2005): Radikal, November 11.

Berkes, Niyazi (1963): The Development of Secularism in Turkey, Montreal: McGill University Press.

Bilgin, Pinar (2005): Turkey's Changing Security Discourses: The Challenge of Globalization, European Journal of Political Research, 44: 175-201.

- (2007): “Only Strong States Can Survive in Turkey's Geography”: The Uses of Geopolitical Truths in Turkey, Political Geography, 26: 740-756.

(unpublished): Re-thinking the Securityness of Secularism in Turkey, unpublished paper.

Bryant, Rebecca (2001): An Aesthetics of Self: Moral Remaking and Cypriot Education, Comparative Studies in Society and History, 43 (3): 583-614.

Büyükanıt, Yaşar (2006): Harp Akademileri 2006-07 Eğitim ve Öğretim Yılı Açış Konuşması, http://www.tsk.mil.tr/bashalk/konusma_mesaj/2006/2006_2007 harpakegitimogretimyiliaciliskonusmasi.htm (accessed 10 January 2007).

Buzan, Barry, Ole Waever, and Jaap de Wilde (1998): Security: A New Framework for Analysis, Boulder, CO: Lynne Rienner. 
Davison, Andrew (1998): Secularism and Revivalism in Turkey: A Hermeneutic Reconsideration, New Haven \& London: Yale University Press.

Deringil, Selim (2007): Simgeden Millete: Abdülhamid'den Mustafa Kemal'e Devlet ve Millet, İstanbul: İletişim.

Erdoğan, Recep Tayyip (2004): Conservative Democracy and the Globalization of Freedom, Speech at the American Enterprise Institute for Public Policy Research, January 29, 2004, available at http://www.aei.org/events/filter. all,eventID.735/transcript.asp. (accessed January 15, 2007).

Göle, Nilüfer (2006): Europe's Encounter with Islam: What Future? Constellations, 13 (2): 248-262.

Hassan, Ümit (2001): Osmanlı: Örgüt-İnanç-Davranıştan Hukuk-İdeolojiye, İstanbul: İletişim.

Hurd, Elizabeth Shakman (2006): Negotiating Europe: The Politics of Religion and the Prospects of Turkish Accession, Review of International Studies, 32: 401-418.

Kafesoğlu, İbrahim and Mehmet Saray (1983): Atatürk İlkeleri ve Dayandiğ Tarihi Temeller, İstanbul: Türk Dünyası Araştırmaları Vakfı.

Kili, Suna (2003): The Atatürk Revolution: A Paradigm of Modernization, İstanbul: İş Bankası Yayınları.

Koçak, Cemil (2006): Neşe Düzel interview, Radikal, November 13.

Mardin, Şerif (1977): Religion in Modern Turkey, International Social Science Journal, 29 (2): 279-297.

(2005): Turkish Islamic Exceptionalism Yesterday and Today: Continuity, Rupture and Reconstruction in Operational Codes, Turkish Studies, 6 (2): 145-165.

McSweeney, Bill (1999): Security, Identity and Interest: A Sociology of International Relations, Cambridge: Cambridge University Press.

Mernissi, Fatima (1991): The Veil and the Male Elite: A Feminist Reinterpretation of Women's Rights in Islam, trans. Mary Jo Lakeland, New York: Basic Books.

Ozankaya, Özer (1981): Atatürk ve Laiklik: Atatürkçü Düşüncenin Temel Niteliği, İstanbul: İş Bankası Yayınları.

Prodromou,ElizabethH.(2005):TurkeybetweenSecularismandFundamentalism? The "Muslimhood Model" and the Greek Orthodox Minority, Brandywine Review of Faith and International Affairs, Spring: 11-22.

Said, Edward (1993): Culture and Imperialism, New York: Knopf.

Tanör, Bülent (1955): Türkiye Cumhuriyetinde Layiklik, Ankara: A.Ü. S.B.F. Yayınları.

Wadud, Amina (2006): Inside the Gender Jihad: Women's Reform in Islam, New York: Oneworld.

Waever, Ole, Barry Buzan, Morten Kelstrup, and Pierre Lemaître (1993): Identity, Migration and the New Security Agenda in Europe, London: Pinter.

Weigel, George (2006): A Question of Freedom, Newsweek, December 8.

White, Jenny B. (2002): Islamist Mobilization in Turkey: A Study in Vernacular Politics, Seattle \& London: University of Washington Press. 
Yavuz, Hakan (ed.) (2006): The Emergence of a New Turkey: Democracy and the AK Parti, Salt Lake City: University of Utah Press.

Yavuz, Ünsal (1990): Atatürk: Imparatorluktan Milli Devlete, Ankara: Türk Tarih Kurumu Yayınları.

Yetkin, Murat (2005): “Beni 28 Şubat ABci Yaptı,” Radikal, May 6. 